\section{ВКЛАД БИЧЕН КЫРГЫСОВНЫ ОНДАР В РАЗВИТИЕ ТОПОНИМИКИ ТУВЫ}

\author{
Надежда Д. Сувандии \\ Тувинский государственный \\ университет, Российская Федерация
}

\section{BICHEN KYRGYZOVNA ONDAR AND HER CONTRIBUTION TO THE STUDY OF THE TOPONYMY OF TUVA}

\author{
Nadezhda D. Suvandii \\ Tuvan State University, \\ Russian Federation
}

\begin{abstract}
Статья посвящена анализу общего вклада филолога, составителя топонимических словарей Тувы Бичен Кыргысовны Ондар (1948-2013) в развитие топонимики республики.

Даны вехи биографии ученой, отрывки из ее личных воспоминаний, которыми она делилась с автором статьи. Окончила с отличием школу, затем - филологический факультет Кызылского государственного педагогического института. Училась в аспирантуре Казанского государственного университета. В 19932. успешно защитила в Институте языкознания РАН кандидатскую диссертацию «Гидронимия Тувы» под руководством известного тюрколога И. В. Кормушина.

Является автором школьных учебников, учебнометодических пособий для студентов и учителей школ республики, по теории и методике обучения русского языка, по вопросам преподавания тувинского языка.

Вся научная жизнь Б. К. Ондар была посвящена исследованию топонимики Тувы. Она объездила с 1980-х г2. все районы Тувы, в сборе материала ей активно помогал супруг Монгун-оол Опанович Ондар. Среди ее основных трудов - «Топонимический
\end{abstract}

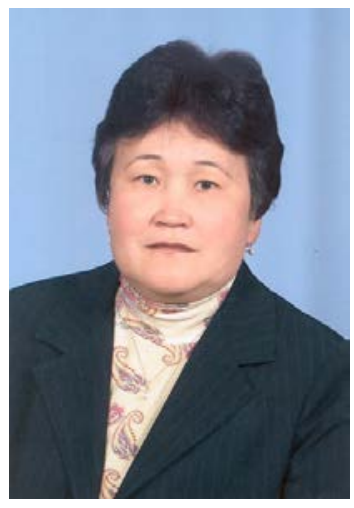

This article analyses the general contribution philologist and compiler of toponymical dictionaries of Tuva Bichen Kyrgyzovna Ondar (1948 - 2013) made to the study of the region's toponymy.

We outline the stages of the scholar's biography and provide fragments of her personal recollections that she had shared with the author of this article. She graduated from school with honors, and later from philological faculty of Kyzyl State Pedagogical Institute. She then entered graduate school at Kazan state University. In 1993 she successfully defended PhD thesis "Hydronymy of Tuva" at the Institute of linguistics of the Russian Academy of Sciences under the supervision of the famous Turkologist I. V. Kormushin. compiled teaching aids on the theory and methods of teaching Russian language for students and school teachers in Tuva.

Her entire research career was devoted to the study of Tuvan place names. She had travelled all parts of the region since 1980s, with her husband helping her gather the materials. Among her main works is "A Toponymical Dictionary of Tuva" (1st edition,
Bichen Kyrgyzovna Ondar wrote textbooks and

Сувандии Надежда Дарыевна - кандидат филологических наук, доцент кафедры тувинской филологии и общего языкознания Тувинского государственного университета. Адрес: 667004, Россия, г. Кызыл, ул. Студенческий квартал 5, каб. 118. Тел.: +7 (394-22) 5-22-50. Эл. адрес: suvandiin@mail.ru Suvandii Nadezhda Daryevna, Candidate of Philology, Associate Professor, Department of Tuvan Philology and General Linguistics, Tuvan State University. Postal address: Office 118, 5 Studencheskii Kvartal St., 667004, Kyzyl, Republic of Tuva, Russian Federation. Tel.: +7 (394-22) 5-22-50. E-mail: suvandiin@ mail.ru 
словарь Тувы» (2004 и 2ое изд. - 2007 г.), который содержит 3200 топонимических единиц со всех районов республики. Автор стремилась раскрыть этимологию каждого топонима, старалась дать полную информацию о географических объектах, изложила мотивацию наименования, которую записывала со слов информантов, сопровождая все ссылками на работы ученых.

В последующих работах автор поднимала основные проблемы топонимики в целом, представляла свои варианты их решения, в том числе рассматривала источники тувинской топонимики, начиная с древнетюркских, китайско-монгольских, русских и др. отнесла русский пласт топонимов как самый поздний.

После кончины Б. К. Ондар направление топонимических исследований Тувы ослабло. Ученые и начинающие исследователи занимаются лишь отдельными вопросами топонимики. Но автор выражает надежду, что научная отрасль найдет новый импульс для развития.

Ключевые слова: Бичен Кыргысовна Ондар; Тува; топонимия Тувы; топонимика; тувинский язык; биография
2004 and 2nd edition, 2007), which contains 3200 toponymical entries from all around the region. The author attempted to trace the etymology of every place name, provide complete information about geographical objects, and explained naming motivation, which she recorded from the words of informants, always referring to the works of scholars.

In her later works, B.K. Ondar raised the issues of place names in general, proposing her own solutions, analyzed the sources of the Tuvan place names - ancient Turkic, Chinese-Mongolian, Russian and others. A special place among stratigraphy of Tuvan place names belongs to Russian as the newest layer in the toponymic system.

After the untimely death of B.K. Ondar, this area of Tuvan toponymical studies has weakened. Scholars and early career researchers have limited their scope only to certain problems of toponymy. The author of this article hopes that this area will see a new impetus for development.

Keywords: Bichen Kyrgyzovna Ondar; Tuva; toponymy of Tuva; toponymy; Tuvan language; biography

\section{Введение}

Одним из наиболее исследованных разделов тувинской ономастики, раздела языкознания, изучающего собственные имена, считается топонимика, обращенная к изучению названий географических объектов.

Появление первых исследований в области топонимики Тувы приходится на вторую половину XIX века, развитие - на вторую половину XX столетия. Ономастика первое время развивалась в рамках языковедческих исследований, и лишь с 70-80-х гг. XX века приобрела самостоятельный статус, отделилась от основной филологической ветви.

Долгое время ономастика Тувы изучалась исследователями, приезжавшими в край со специальными экспедициями, овладевавшими тувинским языком, составлявшими реестры, карты, наброски и пр. Однако, с середины ХХ века тувиноведение стало развиваться за счет местных кадров ученых, в том числе ставших пионерами в целых направлениях. Таким пионером в области топонимики стала тувинская филолог - Бичен Кыргысовна Ондар (1948-2013), составитель основных топонимических словарей Тувы, без изучения которых теперь не обходится ни одна серьезная работа по топонимике региона. 
Данная статья посвящена анализу общего вклада Бичен Кыргысовны Ондар в развитие топонимики Тувы.

\section{Основные вехи развития топонимики Тувы}

В становление и развитие топонимики Тувы немалую роль играли первые научные исследования российских ученых еще во второй половине XIX столетия. Первые сведения о собственных именах в тувинском языке зафиксированы в работе Н. Ф. Катанова (Катанов, 1903), где даны толкования первоначальной семантики ряда топонимов и антропонимов, собранных во время научной экспедиции.

В памятниках рунического письма С. Малова (Малов, 1951), в енисейских эпитафиях И. В. Кормушина (Кормушин, 1997) имеется немало топонимического материала тувинского языка, которые впоследствии стали ценнейшим материалом для исследования ученых различного направления: филологов, историков, этнографов, археологов, географов и т. д.

В 60-х годах XX столетия ученые тувиноведы начали проводить специальные научные исследования по ономастике.

Так в конце 1960-х годов один из основных исследователей тувинского языка Ш.Ч.Сат начал изучать географические названия родного края и опубликовал статью по заметкам, собранным в разных районах республики (Сат, 1969). Б. И. Татаринцев посвятил топонимике ряд публикаций, в которых рассматривал вопросы о географических терминах, об особенностях топонимии и гидронимии некоторых местностей Тувы (Татаринцев, 1973, 1977ab). В одной из своих статей он написал и о функционировании древних топонимов тюркского происхождения на территории Тувы (Татаринцев, 1993). Известным тувинским археологом М. Х. Маннай-оолом в ходе историко-этнографических исследований также собран ценнейший ономастический материал (Маннайоол, 1969, 2004).

Таким образом, тувинская топонимика как отдельная наука стала развиваться во второй половине XX века. Особую роль здесь сыграло творчество Бичен Кыргысовны Ондар.

\section{Вехи биографии Б. К. Ондар}

Бичен Кыргысовна Ондар родилась 7 ноября 1948 г. в многодетной семье простых колхозников Ойдуп-оола Лочуновича Кыргыса и Долзатмы Серээевны Бай-Кара на берегу реки Баян-Кол Улуг-Хемского района. Она всегда с теплотой вспоминала о них и рассказывала нам - коллегам: «Родители мои, простые колхозники, служили нам примером во всем: в жизни, в работе, в любви.Пример моих родителей, людей, воспитавших 11 детей, прославивших себя трудом, 
всегда было мне опорой и поддержкой...» Так, с детства она получила школу труда, которая помогла ей стать старательным, трудолюбивым, выносливым человеком по жизни.

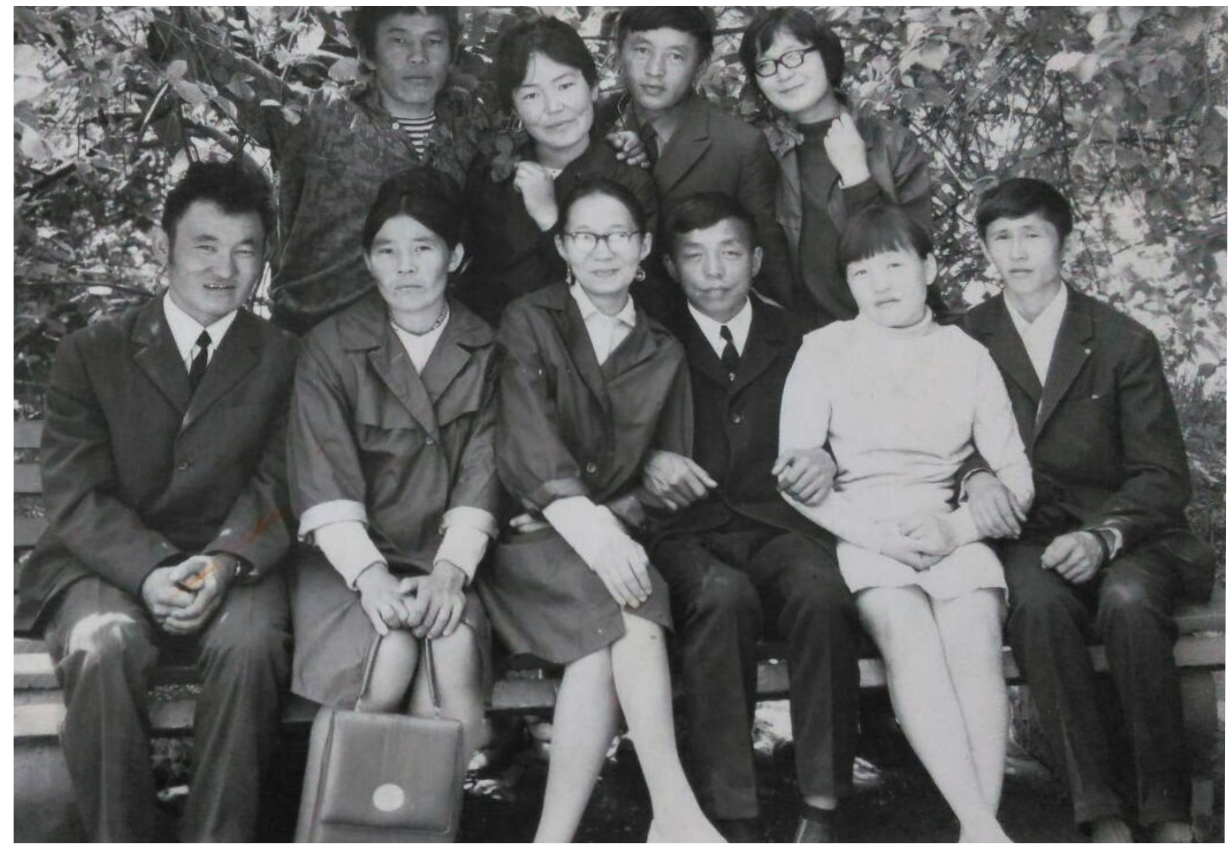

Фото 1. Бичен Ондар (сидит в первом ряду вторая справа) с одноклассниками - учениками школы № 2 г. Кызыла, 1966 г. Photo 1. Bichen Ondar (front row, second from the right) with her classmates at School No.2, Kyzyl, 1966

Вначале Бичен училась в Баян-Кольской школе, затем перевелась в легендарную школу № 2 г. Кызыла, где учились в старших классах самые успевающие девочки и мальчики со всех уголков Республики Тыва. Эту школу окончила почти вся первая волна интеллигенции Тувы. Первые выпускники Коммунстического университета трудящихся Востока (КУТВ) и многие ученые, государственные руководители, работники образования, медицины являются выпускниками именно данной школы.

В 1967 г. с золотой медалью окончила школу. Здесь она и нашла свою первую и единственную любовь всей жизни -Монгун-оола Опановича Ондара. Они были одноклассниками, учились вместе и в школе, и в институте, только на разных факультетах. Поженились они сразу после окончания школы в 1967 г., начали жить и работать в ее родной деревне Терлиг-Хая Кызылского кожууна: она - учителем в начальной школе, а он - на заводе.

В 1970 г. Бичен Кыргысовна поступила на 1 курс филологического факультета Кызылского государственного педагогического института (КГПИ). Бичен

${ }^{1}$ Фотографии любезно предоставлены внучкой Аржаной Анатольевной Сарыглар из личного архива семьи Б. К. Ондар специально для данной публикации. 
Ондар была активисткой-студенткой: работала старостой группы в течение 5 лет, выезжала со студенческими концертными группами в деревни, работала в строительных отрядах, участвовала в научно-практических конференциях, совмещая учебу с работой.

Бичен Кыргысовне посчастливилось быть делегатом первого слета студентов в Москве в 1971 г. За отличную учебу и активное участие в общественной жизни своего института на данном слете студентов она была награждена Ленинской юбилейной медалью, которую ей вручил сам генеральный секретарь Центрального Комитета Коммунистической партии Советского Союза Л. И. Брежнев.

В студенческие годы семья увеличилась - у четы родились две дочери: Елена и Лилия. Супруг Монгун-оол Опанович учился на физико-математическом факультете того же Кызылского государственного педагогического института. Дружная студенческая семья однокурсников Бичен Кыргысовны во главе с куратором Кимой Биче-ооловной Март-оол ${ }^{1}$, о которой всегда с теплотой и благодарностью отзывалась Бичен Ондар, считала девочек общими детьми всей группы.

\section{Работа педагога и организатора}

В 1975 г. Бичен Кыргысовна с отличием окончила институт по специальности «Русский язык и литература, родной язык и литература». Ей, как одной из лучших студентов выпуска, предложили остаться работать ассистентом кафедры тувинской филологии, которую возглавлял в те годы доктор филологических наук, профессор Ш. Ч. Сат. Там и определилось направление творческих работ молодого педагога.

Бичен Кыргысовна рассказывала автору данной статьи, что в становлении ее как ученого большую роль сыграли ее учителя, наставники: доктор филологических наук, профессор Шулуу Чыргал-оолович Сат, доцент Елизавета Боракаевна Салзынмаа, кандидат педагогических наук, доцент Кимаа Бичеооловна Март-оол, доктор филологических наук, профессор Доржу Сенгилович Куулар, доктор филологических наук, профессор Борис Исаакович Татаринцев, кандидат педагогических наук, доцент Регина Рафаильевна Бегзи, кандидат филологических наук Доруг-оол Алдын-оолович Монгуш.

Бичен Кыргысовна с большой ответственностью приступила к преподавательской деятельности в Кызылском пединституте: проводила лекционные и

\footnotetext{
${ }^{2}$ Кандидат педагогических наук, доцент, ведущий методист республики по тувинскому языку, проработала более 10 лет деканом филологического факультета КГПИ и заведующим кафедрой тувинской филологии. В последние годы жизни работала ведущим научным сотрудником секторы языка Тувинского института гуманитарных и прикладных социально-экономических исследований.
} 
практические занятия по языковедческим дисциплинам, работала куратором студенческой группы, принимала активноеучастие в организации и проведении общественных мероприятий факультета.

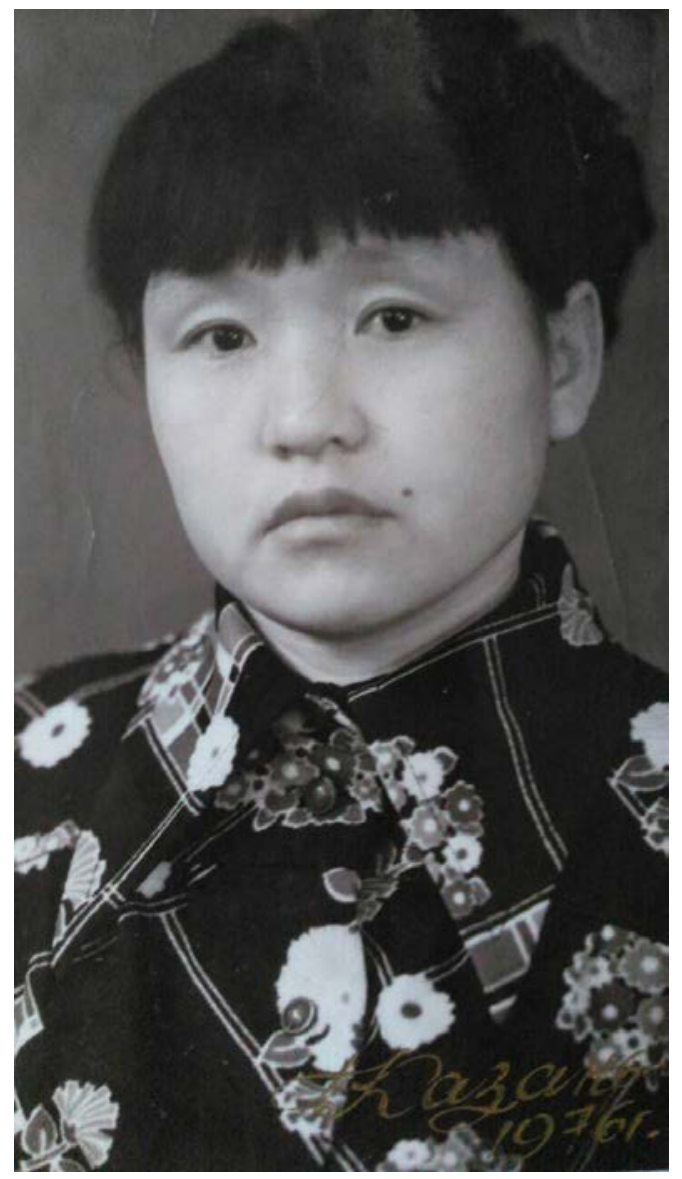

Фото 2. Б. К. Ондар - аспирантка

Казанского государственного университета, 1976 г.

Photo 2. B. K. Ondar as a postgraduate student at Kazan State university, 1976

В педагогической деятельности отличалась творческим подходом. Во время работы в Институте усовершенствования учителей заведующим кафедрой методики русского языка, затем проректором по науке она много ездила по всем школам республики и оказывала научно-методическую помощь учителям русского и родного языков республики, проводила научно-практические конференции.

Слушатели с большим желанием ходили на курсы повышения квалификации, в которых читала лекции и проводила практические занятия, мастер-классы Бичен Кыргысовна.

Проработав несколько лет на кафедре ассистентом, Бичен Кыргысовна поступила в 1977 г. в аспирантуру Казанского государственного университета, 


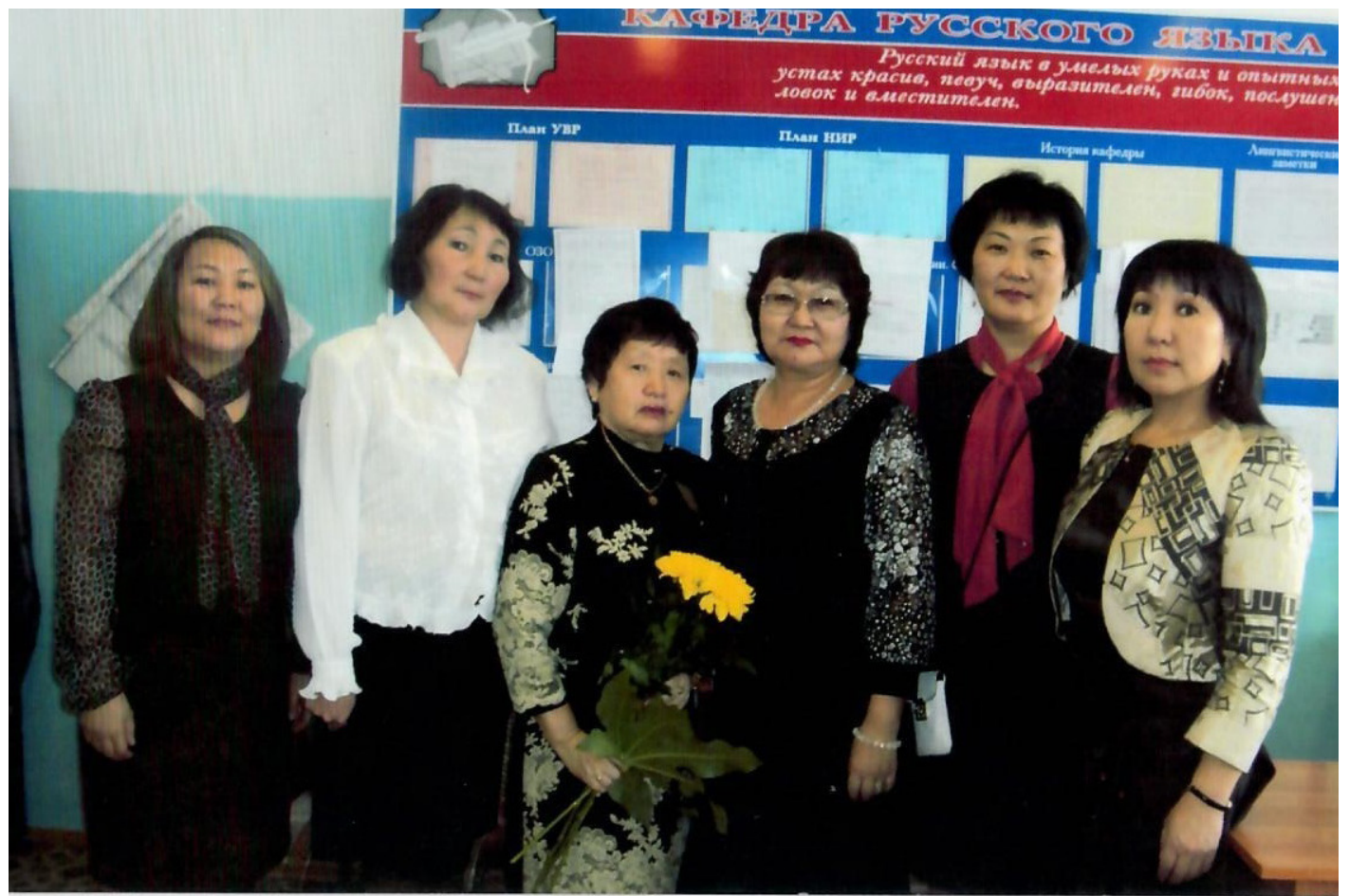

Фото 3. С коллегами по кафедре. Слева направо: к.ф.н., доцент В. С. Ондар, к.ф.н., доцент А. В. Тарыма, к.ф.н., доцент Б. К. Ондар, к.п.н., доцент Г. С. Базыр, к.ф.н., доцент А. У. Даржа, к.соц.н., доцент А. А. Кара-Сал. 2012 г.

Photo 3. Colleagues at the university department. Left to right: C. Phil., Assoc. Prof. V. S. Ondar,

C. Phil., Assoc. Prof. A.V. Taryma, C. Phil., Assoc. Prof. B. K. Ondar, C. Ped., Assoc. Prof. G. S. Bazyr, C. Phil., Assoc. Prof. A. U. Darzha, C. Soc., Assoc. Prof. A. A. Kara-Sal, 2012.

одного из старейших научных школ России на кафедру татарской филологии. Ее научным руководителем стал доктор филологических наук, профессор Г. Ф. Саттаров. Здесь, в стенах знаменитого университета, где учился и работал автор первой научной грамматики тувинского языка Н. Ф. Катанов, продолжился ее творческий путь.

Будучи аспиранткой, старательная молодая женщина, помимо работы в библиотеках, посещала музеи, выставки, концертные залы с целью повышения своего кругозора. Во время летних каникул Б. К. Ондар делала первые шаги в мир науки, выезжая в районы Тувы для сбора материала диссертации.

После возвращения домой, Бичен Ондар продолжила свои научные исследования, работая на кафедре тувинской филологии Кызылского государственного педагогического института, затем - в республиканском Институте усовершенствования учителей Министерства просвещения Тувы.

Результатом кропотливой работы стала подготовка и последующая успешная защита в 1993 г. кандидатской диссертации по теме: «Гидронимия Тувы» (Ондар, 1993) в Институте языкознания Российской Академии наук под руководством известного тюрколога, доктора филологических наук, Почетного профессора Тувинского государственного университета Игоря Валентиновича Кормушина. 
С середины 1990-х годов Б. К. Ондар вернулась работать в свой родной вуз, ставший университетом, на кафедру русского языка. С 2006 по 2012 гг. она заведовала этой кафедрой и, по отзывам коллег, проявила себя умелым руководителем, отличным специалистом и надежным помощником коллегам во всех делах. Под ее чутким руководством молодое поколение преподавателей постигали премудрости преподавательской и научной работы.

В 1997 г. Бичен Кыргысовне присуждено ученое звание доцента.

До последних дней своей жизни она обучала будущих филологов секретам методики обучения русскому языку, риторике и культуре русской речи.

Бичен Кыргысовна - автор школьных учебников, учебно-методических пособий для студентов и учителей школ республики, которые она готовила самостоятельно или

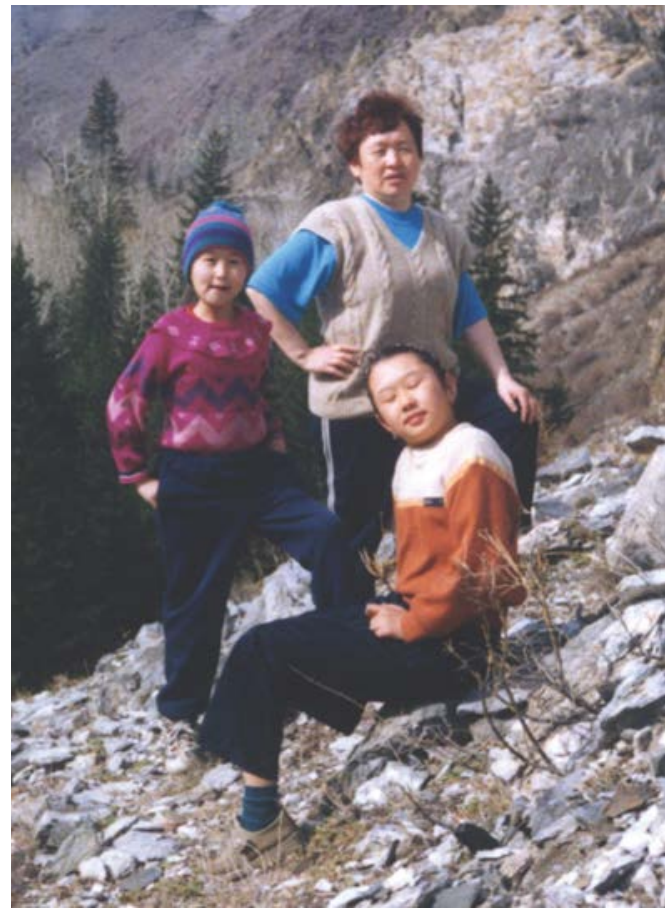

Фото 4. Б. К. Ондар на выезде с внучками Аржааной и Аясмой, 2002 г. Photo 4. B. K. Ondar with her granddaughters Arzhaana and Ayasma, 2002. совместно с коллегами. К ним относятся «Тувинский язык» для студентов педагогического училища (Сат Бичелдей, Ондар, 1993), «Тыва дыл. 10-11 класс» (Ойдан-оол и др., 2007), «Теория и методика обучения русскому языку» (учебно-методическое пособие) (Ондар, 2007b) и др.

\section{Топонимические исследования}

Вся научная жизнь Б. К. Ондар посвящена исследованию топонимики Тувы. Ее монографические публикации вызывают до сих пор большой интерес не только ученых, но и широкого круга читателей.

С 1980-х годов она объездила всю республики, собирая материал к своей научной работе.Ее «личным водителем» и помощником был супруг Монгун-оол Опанович. Она вспоминала, что муж ей помогал даже в карточки записывать собранные топонимы, чтобы ей удобно было их анализировать.

Они ездили на своей личной автомашине, встречались с информантами. Бичен Кыргысовна беседовала и записывала, а Монгун-оол Опанович делал фотографии информантов и географических наименований, позднее для монографий записи на видеокамере.Проводилось также анкетирование студентов Тувинского 
государственного университета, сельских учителей, находящихся на курсах повышения квалификации.

В кандидатской диссертации, состоящей из 3 глав, Бичен Ондар представила первое комплексное историко-лингвистическое исследование названий водных объектов в тувинском языкознании (Ондар, 1993). Она выявила значительное количество гидрографических терминов, которые были подвергнуты сопоставительно-сравнительному анализу. При этом были определены способы гидронимообразования, выявлены структурные типы гидронимов. В диссертации впервые раскрывается этимология ряда древних гидронимов, неясных с точки зрения современного тувинского языка.

Первый большой труд ученой назывался «Топонимический словарь Тувы» (Ондар, 2004), который содержит 3200 топонимических единиц со всех районов Республики Тыва.

Словарь состоит из предисловия, введения, списка аппелятивов ${ }^{1}$, встречающихся в топонимии Тувы, списка сокращений, основного корпуса словаря и библиографического списка. Словарные статьи расположены в алфавитном порядке с соблюдением орфографии, предусмотренной Инструкцией по передаче на картах географических названий Тувы. В словаре использованы не только материалы самого автора, но и из других источников, в частности, материалы диалектологических экспедиций Тувинского научноисследовательского института (нынешнее название - ТИГПИ), Национального краеведческого музея, материалы местных газет и др. Привлекались также метариалы карт и экспедиций русских путешественников Катанова, ГрумГржимайло и др. (Ондар, 2004: 4).

Автор стремилась раскрыть этимологию каждого топонима, постаралась дать полную информацию о географических объектах, изложила мотивацию наименования, которую записывала со слов информантов, а также ссылки на работы ученых.

Например, Азас (Абзас, или другое название Тожу) - озеро в Тодже. Название озера в виде Азас возникло недавно. В русских исторических документах Тойи-куль, Тоджи-куль. Существует несколько объяснений для этого названия. С. И. Вайнштейн (Вайнштейн, 1961: 22), А. П. Дульзон (Дульзон, 1964: 250) считают Азас и Казас кетскими гидронимами (сэс, зас в кетском языке 'родник'). По мнению В.Я. Бутанаева (Бутанаев, 1995: 6), гидронимы с зас и cac непонятны хакасским жителям, зато объяснимы в кетском языке: Томзас 'черная река', Кайзас - 'лосиная речка', Казас - 'песчаная река'). Л. Р. Кызласов считает зас и сас тюркскими производными от угорского сос - 'речка' и относит к ним Канзас и Анзас в Хакассии, Азас и Казас в Туве (Кызласов, 1959). Местные жители связывают название Азас с сочетанием аза - 'чертов горностай',

${ }^{1}$ Лингвистический термин, синоним термина имя нарицательное. 
мотивируя это тем, что в этих местах обитал такой горностай (видеть и убивать его было нельзя). Это типично народная этимология. Правомерной же Б. К. Ондар назвала гипотезу о единичности названия Азас в Туве и объяснение его от кетского зас, сас - 'река, родник' (Ондар, 2004: 37).

При этом в издании автор написала, что работа над словарем продолжится. И попросила читателей дать свои замечания и пожелания. В 2007 г., по их замечаниям и пожеланиям, Бичен Кыргысовна переработала, дополнила словарь и переиздала (Ондар, 2007).

На следующий же год Б. К. Ондар издала монографический сборник научнометодических статей «Тувинская топонимика: проблемы, поиски, решения» (Ондар, 2008а). В нем представлены научные и научно-методические статьи автора, опубликованные в период всей научно-педагогической деятельности по отдельным вопросам тувинской топонимики, также научно-методические статьи по вопросам преподавания русского языка в вузе и в школе. По мнению автора, опубликованные статьи по русской, тувинской, алтайской топонимике будут способствовать решению вопросов национально-регионального компонента в преподавании русского языка в национальной школе. Сборник также может обеспечить методическую подготовку учителей в соответствии с последними тенденциями содержания обучения в высшей и общеобразовательной школе (там же: 3). В ней автор изложила основные проблемы топонимики в целом, представила свои варианты их решения.

Б. К. Ондар не останавливалась на достигнутом и продолжала свои исследования, обобщая материал и анализируя его на теоретическом уровне. Следующим итогом ее работ стала монография «Тувинская топонимия. Сопоставительный анализ топонимии Тувы с топонимией Южной Сибири и других тюркоязычных территорий» (Ондар, 2008b). В работе рассматриваются источники тувинской топонимики, начиная с древнетюркских, китайско-монгольских, русских и др. Определены основные аппелятивы, употребляющиеся в тувинской топонимии. Приведены структурно-словообразовательный анализ тувинских топонимов, их лексико-семантическая классификация. Отдельное место в работе отведено стратиграфии топонимов, где автором выделены пять слоев: тюркский, монгольский, русский, кетский, самодийский.

Особое место в стратиграфии тувинских топонимов Б. К. Ондар относит русский как самый поздний пласт топонимической системы по времени образования. «Русская топонимия Тувы, - писала она, - оказывается наименее исследованной, хотя в топонимической системе данный пласт является наиболее обширным после монгольского (Ондар, 2011: 3). Это и стало следующим шагом ее исследований - изучение истории появления русских географических наименований на территории Тувы, а также источники их изучения - в монографии «Русская топонимия Тувы» (Ондар, 2011). Автор проанализиро- 
вала происхождение русских топонимов и их структурно-словообразовательные особенности. Отдельно выявлены и аппелятивы в русской топонимии Тувы.

В многочисленных научных статьях (их более 80) Бичен Кыргысовна освещает не только проблемы исследования топонимики Тувы, но и сравнительную лексикологию, фразеологию, методику обучения русского и тувинских языков.

Бичен Кыргысовна Ондар была неутомимым тружеником, одним из выдающихся педагогов и ученых республики, чьи научные труды будут настольными книгами не только исследователей тувинской ономастики, но и всех ученыхтюркологов.

\section{Заключение}

У Бичен Кыргысовны было много планов. В первую очередь, она хотела выпустить учебно-методическое пособие по методике обучения русскому языку в национальной школе для студентов филологического факультета Тувинского государственного университета; во-вторых, продолжить работу по исследованию топонимии Тувы. Но, к сожалению, трагическая гибель Бичен Кыргысовны в 2013 г. оборвала жизнь и творческий путь блестящего ученого, замечательного педагога.

Надо сказать, что много сил она отдавала и общественной работе, являлась членом экспертной комиссии учебно-методического совета (УМС) Тувинского государственного университета, членом УМС Министерства образования и науки Республики Тыва, членом Ученого совета университета, председателем жюри городских, республиканских олимпиад школьников по русскому языку, научно-практической конференции школьников «Шаг в будущее», председателем жюри республиканского конкурса «Учитель года»...

За заслуги в обучении молодого поколения в 2005 г. она была награждена нагрудным знаком «Почетный работник общего и профессионального образования Российской Федерации», в 2007 г. - нагрудным знаком «За вклад в развитие университета».

К сожалению, у Б. К. Ондар не осталось учеников, которые занимались бы непосредственно темой топонимики Тувы. Отдельные вопросы топонимики решают ученые кафедры тувинской филологии и общего языкознания Тувинского государственного университета и сектора языка Тувинского института гуманитарных и прикладных социально-экономических исследований. Выпускные квалификационные работы по ономастике пишут студенты филологического факультета Тувинского государственного университета. Но мы надеемся, что топонимические исследования Тувы найдут новый импульс для развития, что дело жизни Бичен Кыргысовны подхватит новый ученый или даже коллектив, которые продолжат реализовывать ее планы. 


\section{СПИСОК ЛИТЕРАТУРЫ}

Катановъ, Н. Ф. (1903) Опытъ изслъдованія урянхайскаго языка, съ указаніемъ главнъйшихъ родственныхъ отношеній его къ другимъ языкамъ тюркскаго корня. СПб.: Типо-литография Императорского университета. 1600 с.

Кормушин, И. В. (1997) Тюркские енисейские эпитафии. Тексты и исследования / отв. ред. Э. Р. Тенишев. М. : Наука. 303 с.

Малов, С. Е. (1951) Памятники древнетюркской письменности. Тексты и исследования. М.-Л. : Изд-во АН СССР. Т. 1.451 с.

Маннай-оол, М. Х. (1969) Аржаанның улуг хорумунуң чажыттары [Тайна кургана Аржана]. Кызыл : ТНИИЯЛИ. 57 с. (На тув. яз.).

Маннай-оол, М. Х. (2004) Тувинцы: происхождение и формирование этноса. Новосибирск : Наука. 166 с.

Ойдан-оол, А. К., Ондар, Б. К., Доржу, К. Б., Куулар, Е. М. (2007) Тувинский язык: учебник для 10-11 классов средней школы. Кызыл : Тувинское книжное издательство. 270 с.

Ондар, Б.К. (1993) Гидронимия Тувы : автореф. дисс.... канд. филол. н. М. 19 с.

Ондар, Б. К. (2004) Топонимический словарь Тувы. Абакан : Изд-во Хакасского государственного университета им. Н. Ф. Катанова. 256 с.

Ондар, Б.К.(2007а) Топонимический словарь Тувы. 2-е изд.Кызыл :Тувинское книжное издательство. 550 с.

Ондар, Б. К. (2007b) Теория и методика обучения русскому языку : учебнометодическое пособие. Кызыл : Редакционно-издательский отдел ТувГУ. 82 с.

Ондар, Б. К. (2008а) Тувинская топонимика: проблемы, поиски, решения. Кызыл : Редакционно-издательский отдел ТувГУ. 233 с.

Ондар, Б. К. (2008b) Тувинская топонимия. Сопоставительный анализ топонимии Тувы с топонимами Южной Сибири и других тюркоязычных территорий. Кызыл : Тувинское книжное издательство. 296 с.

Ондар, Б. К. (2011) Русская топонимия Тувы. Кызыл : Редакционно-издательский отдел ТувГУ. 168 с.

Сат, Ш. Ч. (1969) Заметки по топонимике Тувы // Материалы конференции «Этногенез народов Северной Азии» / отв. ред. Е. И. Убрятова. Новосибирск : б./и. 247 с. С. $232-234$.

Сат, Ш. Ч., Бичелдей, К. А., Ондар, Б. К. (1993) Тувинский язык: учебник для студентов. Кызыл : Тувинское книжное издательство. 270 с.

Татаринцев, Б. И. (1973) Об особенностях топонимии Северо-Восточной Тувы // Происхождение аборигенов Сибири и их языков / отв. ред. А. П. Дульзон. Томск: Изд-во Томского университета. 235 с. С. 142-144.

Татаринцев, Б. И. (1977а) Местные географические термины северо-восточной Тувы // Советская тюркология Вып. 5. / гл. ред. М. Ш. Ширалиев. Баку : Тип-я им. 26-ти бакинских комиссаров. 112 с. С. 18-26. 
Татаринцев, Б. И. (1977b) О топонимии бассейна р. Каа-Хем // Тувинский язык и литература в послеоктябрьский период / отв. ред. Д. А. Монгуш. Кызыл: Типия управления по делам издательств, полиграфии и книжной торговли Совета Министров Тув. АССР. 192 с. С. 88-99.

Татаринцев, Б. И. (1993) О некоторых древних топонимах тюркского происхождения на территории Тувы // Вопросы тувинского языкознания: сборник материалов / отв. ред. Д. А. Монгуш, Б. И. Татаринцев. Кызыл : Новости Тувы. 128 c. C. $105-113$.

Дата поступления: 13.06.2018 2.

\section{REFERENCES}

Katanov, N. F. (1903) Opyt izsledovaniia uriankhaiskago iazyka, s ukazaniem glavneishikh rodstvennykh otnoshenii ego $k$ drugim iazykam tiurkskago kornia [An essay on the Uryanghai language, indicating the most important kinship ties between him and the other languages of the Turkic root]. St. Petersburg, Tipo-litografiia Imperatorskogo universiteta. 1600 p. (In Russ.).

Kormushin, I. V. (1997) Tiurkskie eniseiskie epitafii. Teksty i issledovaniia [Turkic Yenisei epitaphs. Texts and studies], ed. by E. R. Tenishev. Moscow, Nauka. 303 p. (In Russ.).

Malov, S. E. (1951) Pamiatniki drevnetiurkskoi pis'mennosti. Teksty $i$ issledovaniia [Monuments of ancient Turkic writing. Texts and research]. Moscow, Leningrad, AN SSSR Publ. Vol. 1. 451 p. (In Russ.).

Mannai-ool, M. Kh. (1969) Arzhaannyң ulug khorumunuң chazhyttary [The Mystery of Arzhan mound]. Kyzyl, TNIIIaLI. 57 p. (In Tuv.).

Mannai-ool, M. Kh. (2004) Tuvintsy: proiskhozhdenie i formirovanie etnosa [Tuvans: origin and formation of an ethnic group]. Novosibirsk, Nauka. 166 p. (In Russ.).

Oidan-ool, A. K., Ondar, B. K., Dorzhu, K. B. and Kuular, E. M. (2007) Tuvinskii iazyk [Tuvan language]. Textbook for 10-11 grades of high school. Kyzyl, Tuvinskoe knizhnoe izdatel'stvo. 270 p. (In Russ.).

Ondar, B. K. (1993) Gidronimiia Tuvy [Hydronyms Of Tuva]: Thesis of Diss.... Candidate of Philology. Moscow. 19 p. (In Russ.).

Ondar, B. K. (2004) Toponimicheskii slovar' Tuvy [A toponymic dictionary of Tuva]. Abakan, Izd-vo Khakasskogo gosudarstvennogo universiteta im. N. F. Katanova. 256 p. (In Russ.).

Ondar, B. K. (2007a) Toponimicheskii slovar' Tuvy [A toponymic dictionary of Tuva]. 2nd ed. Kyzyl, Tuvinskoe knizhnoe izdatel'stvo. 550 p. (In Russ.).

Ondar, B. K. (2007b) Teoriia i metodika obucheniia russkomu iazyku : uchebno-metodicheskoe posobie [Theory and methods of teaching the Russian language. An educational and methodical manual]. Kyzyl, Redaktsionno-izdatel'skii otdel TuvGU. 82 p. (In Russ.).

Ondar, B. K. (2008a) Tuvinskaia toponimika: problemy, poiski, resheniia [Tuvan toponyms: problems, investigations, solutions]. Kyzyl, TuvGU. 233 p. (In Russ.). 
Ondar, B. K. (2008b) Tuvinskaia toponimiia. Sopostavitel'nyi analiz toponimii Tuvy s toponimami Iuzhnoi Sibiri i drugikh tiurkoiazychnykh territorii [Tuvan toponyms. A comparative analysis of toponyms of Tuva with those of southern Siberia and other Turkicspeaking territories]. Kyzyl, Tuvinskoe knizhnoe izdatel'stvo. 296 p. (In Russ.).

Ondar, B. K. (2011) Russkaia toponimiia Tuvy [Russian placenames in Tuva]. Kyzyl, Redaktsionno-izdatel'skii otdel TuvGU. 168 p. (In Russ.).

Sat, Sh. Ch. (1969) Zametki po toponimike Tuvy [Notes on the toponyms of Tuva]. In: Materialy konferentsii «Etnogenez narodov Severnoi Azii» [Proceedings of the conference "Ethnogenesis of the peoples of North Asia"] / Ed. by E. I. Ubriatova. Novosibirsk, s. n. 247 p. Pp. 232-234. (In Russ.).

Sat, Sh. Ch., Bicheldei, K. A. and Ondar, B. K. (1993) Tuvinskii iazyk [The Tuvan language]. Textbook for students. Kyzyl, Tuvinskoe knizhnoe izdatel'stvo. 270 p. (In Russ.).

Tatarintsev, B. I. (1973) Ob osobennostiakh toponimii Severo-Vostochnoi Tuvy [On the peculiarities of the toponyms of the North-Eastern Tuva]. In: Proiskhozhdenie aborigenov Sibiri i ikh iazykov [Origin of the natives of Siberia and their languages] / Ed. by A. P. Dul'zon. Tomsk, Tomskii universitet Publ. 235 p. Pp. 142-144. (In Russ.).

Tatarintsev, B. I. (1977a) Mestnye geograficheskie terminy severo-vostochnoi Tuvy [Local geographical terms of North-Eastern Tuva]. In: Sovetskaia tiurkologiia [Soviet Turkology]. Vol. 5. / Ed. by M. Sh. Shiraliev. Baku, Tip-ia im. 26-ti bakinskikh komissarov. 112 p. Pp. 18-26. (In Russ.).

Tatarintsev, B. I. (1977b) O toponimii basseina r. Kaa-Khem [On the toponyms of the river Kaa-Khem]. In: Tuvinskii iazyk i literatura $v$ posleoktiabr'skii period [Tuvan language and literature in the post-October period] / Ed. by D. A. Mongush. Kyzyl, Tipiia upravleniia po delam izdatel'stv, poligrafii i knizhnoi torgovli Soveta Ministrov Tuv. ASSR. 192 p. Pp. 88-99. (In Russ.).

Tatarintsev, B. I. (1993) O nekotorykh drevnikh toponimakh tiurkskogo proiskhozhdeniia na territorii Tuvy [On some ancient toponyms of Turkic origin on the territory of Tuva]. In: Voprosy tuvinskogo iazykoznaniia [Tuvan linguistics]. Collection of materials / Ed. by D. A. Mongush and B. I. Tatarintsev. Kyzyl, Novosti Tuvy. 128 p. Pp. 105-113. (In Russ.).

Submission date: 13.06.2018.

\section{Для циитирования:}

Сувандии Н. Д. Вклад Бичен Кыргысовны Ондар в развитие топонимики Тувы [Электронный ресурс] // Новые исследования Тувы. 2018, № 3. URL: https://nit.tuva. asia/nit/article/view/785 (дата обращения: дд.мм.гг.). DOI: 10.25178/nit.2018.3.1

\section{For citation:}

Suvandii N. D. Bichen Kyrgyzovna Ondar and her contribution to the study of the toponymy of Tuva. The New Research of Tuva, 2018, no. 3 [on-line] Available at: https://nit. tuva.asia/nit/article/view/785 (accessed: ...). DOI: 10.25178/nit.2018.3.1 